\title{
Articles with authors affiliated to Brazilian institutions published from 1994 to 2003 with 100 or more citations: II - Identification of thematic nuclei of excellence in Brazilian science
}

\author{
ROGERIO MENEGHINI and ABEL L. PACKER \\ BIREME/PAHO/WHO - Latin American and Caribbean Center on Health Sciences Information / \\ Pan American Health Organization / World Health Organization, \\ Rua Botucatu 862, 04023-901 São Paulo, SP, Brasil \\ UNIFESP - Universidade Federal de São Paulo, Departamento de Informática em Saúde - DIS \\ Rua Botucatu 862, 04023-901 São Paulo, SP, Brasil \\ Manuscript received on May 2, 2006; accepted for publication on May 31, 2006; \\ contributed by ROGERIO MENEGHINI*
}

\begin{abstract}
Articles with 100 citations or more in the scientific literature and with at least one author with Brazilian affiliation, were identified in the Thomson-ISI (Institute for Scientific Information) Web of Science bibliometric database covering a 10-year period, from 1994 to 2003 (see Packer and Meneghini 2006); 248 (0.23\%) out of a total of 109,916 articles with Brazilian affiliation were identified. This study was primarily carried out to identify thematic nuclei of excellence in research that had major impact in the international literature. Twelve of these nuclei in the fields of Biomedicine, Medicine, Biology, Physic, Chemistry and Astronomy were considered outstanding and their genesis and development were described. The weight of factors such as international collaboration and network organization are distinct in these areas and the reasons for that are discussed.
\end{abstract}

Key words: bibliometrics, information services, information storage and retrieval, science, scientometrics, impact factor, scientific policy, scientific institutions, Brazil.

\section{INTRODUCTION}

Studies on the correlation between scientific quality and citations, at the level of institutions, areas of science, journals and scientists have been performed along the last four decades and many of them resulted in meaningful statistic values for such a correlation. (Garfield and Small 1978, Moed 2005, Aksnes and Sivertsen 2004, Oppenheim 1997, Lee et al. 2002, Saha et al. 2003. One of these studies (Aksnes and Sivertsen 2004) was focused on the

\footnotetext{
*Member Academia Brasileira de Ciências Correspondence to: Rogerio Meneghini

E-mail: rogmeneg@bireme.br
}

highly cited articles of a nation and concluded that they may be useful in creating awareness towards the sub-areas of great influence on the national performance. In a recently published article, David King analyzed the outcomes of investment in research to measure quality at a national level and to compare it with the international scenario (King 2004). As a benchmark, King took the $1 \%$ top tier of articles with the highest citation index in the period 19932002 for 31 countries, encompassing $98 \%$ of the most-cited articles within this sample. Brazil was among these countries.

A similar methodology was applied in the 
present study (Packer and Meneghini 2006). A list of the articles with 100 or more citations was obtained from data recovered in the Thomson-ISI Web of Science bibliometric database, referring to the 1994-2003 timeframe. A total of 248 articles with at least one Brazilian affiliation were identified. In this paper it is described that 114 of these articles $(46 \%)$ were found to be within the perimeter of 11 distinct sub-areas, thus defining clusters of high performance in Brazilian science: Amazon forest, cardiac surgery, oxidative metabolism and free radicals, chemical catalysis, genomics, neurosciences, physics of particles, quantum physics, human genetics, infectious diseases and contraceptive-vascular disease correlation.

As discussed at the end, the importance of international collaboration and network mode of operation were fundamental for the shaping of the clusters.

\section{RANKING OF THE MOST-CITED}

Although caution is necessary to draw conclusions from the ranking data, these are useful for some interesting considerations. Therefore, Table I shows the top most-cited articles: in a decreasing order of citations, the 37 articles from 1994 to 2003 that received more than 250 citations. It shows that as more stringent one becomes with the criteria of selection of articles the higher is the weight of international collaboration and network efforts of organization.

There is a considerable prevalence of medical and epidemiological investigations through multinational networks. They are studies on the incidence of diseases, efficacy and side effects of drugs and results of new treatment techniques or surgeries. There are 18 articles of this nature, accounting for virtually half of the articles included in the ranking in Table I. These 18 articles present an average of 9.4 countries per article, which is much higher than the general average of the 248 articles found in this survey, that is, 3.8 countries per article (Packer and Meneghini 2006). They show an average of 21 authors per article. Several institutions and authors received a high number of citations with that type of article. These are very important researches, but from the point of view of indicating individual citation of the investigators, or institutional citation, they deserve a differentiated assessment.

On the other hand, there are 17 articles on basic research reports, accounting for an average of just 2.1 countries per article and 6.9 authors per article, which is closer to the traditional pattern of scientific publications.

It also draws our attention that only 4 articles (articles 5, 19, 20, 24) were affiliated only to Brazil, that is $10.8 \%$, as compared to $15.7 \%$ in the total context of 248 articles of this study (Packer and Meneghini 2006). Again, the stringency degree, from 100 to 250 citations per article, was achieved with an even stronger international collaboration. It is also noteworthy that $67.6 \%$ of articles in Table I have authors affiliated to the United States, whereas in the main scenario this figure was $58 \%$ (Packer and Meneghini 2006). There is a tendency of higher impact for articles co-authored by American authors. With these indicators, one could not conclude if the participation of American authors brings results with a trend to produce higher quality research or if they involve a psychological-social behavior, in other words, Americans citing more Americans. (Moed 2005, King 2004).

\section{IDENTIFICATION OF FIELDS AND CENTERS OF EXCELLENCE}

The use of the indicator citations per article enables mapping the impacting research activities in Brazil. It is important to stress, however, that this indicator is not excluding. As already mentioned, the scientific fields are distinguished in terms of tendency of citations due to several reasons. For example, in another study we detected articles with Brazilian affiliation which had fifty or more citations, during the same period of this research (unpublished results). This research identified approximately one thousand articles. In this case the digging went deeper and it was possible to identify fields that were not contemplated in this article, or were con- 
TABLE I

Ranking of the ISI articles with Brazilian affiliation and over 250 citations from 1994 to 2003.

1 - Bosch FX, Manos MM, Munoz N et al.

Prevalence of human papillomavirus in cervical-cancer - A worldwide perspective

Journal of the National Cancer Institute 87 (11): 796-802 Jun 71995

Times Cited: 1155, Spain, USA, England, Benin, Mali, Algeria, Thailand, Brazil, Panamá,

Canadá, Tanzânia, Guinea Bissau, Philippines, Bolivia, Indonesia, Germany, Colômbia,

Argentina, Paraguay, Cuba, Chile, Uganda, Poland, Australia (36). Hosp Clin Porto Alegre, UFRGS.

2 - Bombardier C, Laine L, Reicin A et al.

Comparison of upper gastrointestinal toxicity of rofecoxib and naproxen in patients with rheumatoid arthritis.

New England Journal of Medicine 343 (21): 1520-1528 Nov 232000

Times Cited: 941, Canada, USA, Mexico, Australia, Brazil, England, Norway (13)

Division of Rheumatology, Department of Medicine, Esc Paul Medic, UNIFESP.

3 - Deheer WA, Chatelain A, Ugarte D

A carbon nanotube field-emission electron source

Science 270 (5239): 1179-1180 Nov 171995

Times Cited: 864 Switzerland, Brasil (3). Lab Nacl Luz Sincrotron, Campinas, SP

4 - Collins R, Peto R, Flather M et al.

ISIS-4 - A randomized factorial trial assessing early oral captopril, oral mononitrate, and intravenous magnesium-sulfate in 58,050 patients with suspected acute myocardial-infarction

Lancet 345(8951): 669-685 Mar 181995

Times Cited: 684, England, Argentina, Australia, Belgium, Brazil, Canada, Chile, Finland,

France, Germany, Greece, Hungary, Israel, Italy, Mexico, Netherlands, New Zealand, Norway,

Portugal, South Africa, Spain, Switzerland, England, USA, Uruguay, Venezuela (74).

Inst Dante Pazzaneste Cardiol, São Paulo.

5 - Amato MBP, Barbas CSV, Medeiros DM et al.

Effect of a protective-ventilation strategy on mortality in the acute respiratory distress syndrome

New England Journal of Medicine 338 (6): 347-354 Feb 51998

Times Cited: 655 Brazil (12). Hosp Clin, Div Pulm, Resp Intens Care Unit, USP.

6 - Carpenter CCJ, Cooper DA, Fischl MA et al.

Antiretroviral therapy in adults - Updated recommendations of the International

AIDS Society-USA Panel

JAMA - Journal of the American Medical Association 283 (3): 381-390 Jan 192000

Times Cited: 600, USA, Australia, Spain, England, Canada, Brazil, Italy, France (17).

Univ Fed Rio de Janeiro

7 - Said A, Pearlman WA

A new, fast, and efficient image codec based on set partitioning in hierarchical trees

IEEE Transactions on circuits and systems for video technology 6 (3): 243-250 Jun 1996

Times Cited: 597, Brazil, USA (2). Univ Campinas, Fac Elect Engn.

8 - Morice M, Serruys PW, Sousa JE et al.

A randomized comparison of a sirolimus-eluting stent with a standard stent for

coronary revascularization.

New England Journal of Medicine 346 (23): 1773-1780 Jun 62002

Times Cited: 590 Brazil, France, Netherlands, Mexico, Italy, Germany, Hungary, USA (10).

INCOR, Hosp Clin, USP 
TABLE I (continuation)

9 - Racusen LC, Solez K, Colvin RB et al.

The Banff 97 working classification of renal allograft pathology

Kidney International 55 (2): 713-723 Feb 1999

Times Cited: 585 Brazil, USA, Canada, England, Scotland, France, Argentina, Denmark,

Finland, North Ireland, Switzerland, Norway (41). USP, Fac Med

10 - Fried MW, Shiffman ML, Reddy KR et al.

Peginterferon alfa-2a plus ribavirin for chronic hepatitis $\mathrm{C}$ virus infection.

New England Journal of Medicine, 347 (13): 975-982 Sep 26

Times Cited: 515 USA, Australia, Brazil, Germany, Spain, Italy (12).

Fac Cie Med, UNICAMP, Campinas

11 - Gluckman E, Rocha V, BoyerChammard A et al.

Outcome of cord-blood transplantation from related and unrelated donors

New England Journal of Medicine 337 (6): 373-381 Aug 71997

Times Cited: 499, France, Italy, Brazil, Spain (10). Hosp Clin, UFPR, Curitiba;

Hosp Albert Einstein, São Paulo

12 - Vogt PH, Edelmann A, Kirsch S et al.

Human Y chromosome azoospermia factors (AZF) mapped to different subregions in Yq11

Human molecular genetics 5 (7): 933-943 Jul 1996

Times Cited: 416, Brazil, Germany (13). UNICAMP, Inst Biol, Campinas

13 - Richard I, Broux O, Allamand V et al.

Mutations in the proteolytic-enzyme calpain-3 cause limb-girdle muscular-dystrophy type-2A

Cell 81 (1): 27-40 Apr 71995

Times Cited: 402 France, Brazil, USA (18). Inst Biocienc, USP

14 - Holben BN, Eck TF, Slutsker I et al.

AERONET - A federated instrument network and data archive for aerosol characterization

Remote Sensing of Environment 66 (1): 1-16 Oct 1998

Times Cited: 402 USA, France, Brazil, Japan (13). Inst Pesq Espac, S Jose dos Campos

15 - Weaver WD, Simes RJ, Betriu A et al.

Comparison of primary coronary angioplasty and intravenous thrombolytic therapy for acute myocardial infarction - A quantitative review

JAMA - Journal of the American Medical Association 278 (23): 2093-2098 Dec 171997

Times Cited: 387 USA, Australia, Spain, Netherlands, Argentina, Brazil, Italy (11).

Hosp Unicor, São Paulo

16 - Girardi L, Bressan A, Bertelli G et al.

Evolutionary tracks and isochrones for low- and intermediate-mass stars: From 0.1.5 to

$7 \mathrm{M}$-circle dot and from $\mathrm{Z}=0.0004$ to 0.03

Astronomy \& Astrophysics Supplement Series 141 (3): 371-383 Feb 2000

Times Cited: 377 Italy, Germany, Brazil (4). Inst Fis, UFRGS

17 - Zakhidov AA, Baughman RH, Iqbal Z, Cui CX, Khayrullin I, Dantas SO,

Marti I, Ralchenko VG

Carbon structures with three-dimensional periodicity at optical wavelengths

Science, 282 (5390): 897-901 Oct 301998

Times Cited: 350 USA, Uzbekistan, Brazil, Russia (8). Dept Fis, UF Juiz de Fora, MG 


\section{TABLE I (continuation)}

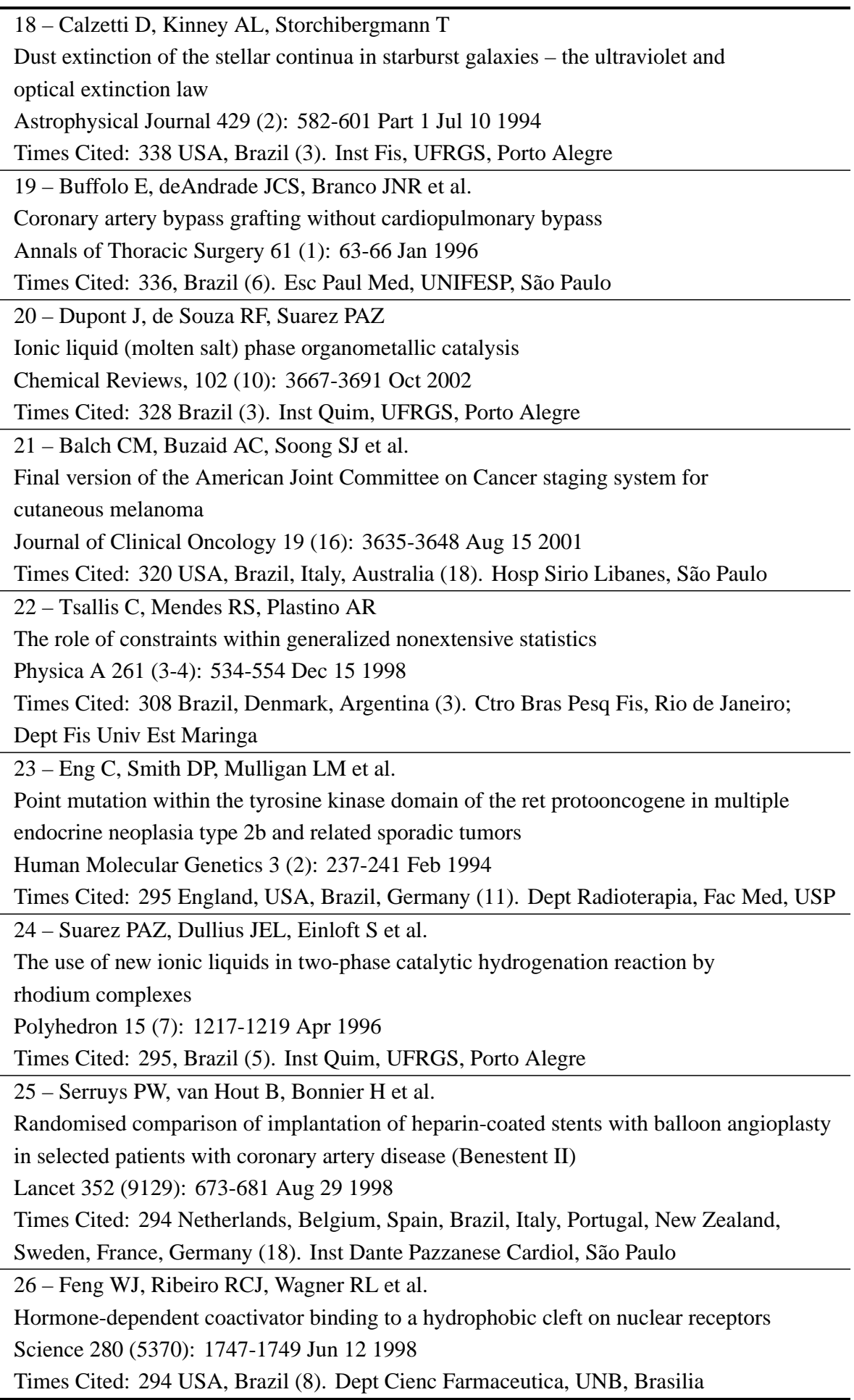


TABLE I (continuation)

27 - Grines CL, Cox DA, Stone GW et al.

Coronary angioplasty with or without stent implantation for acute myocardial infarction New England Journal of Medicine 341 (26): 1949-1956 Dec 231999

Times Cited: 294 Brazil, Spain, USA, France (12). Inst Dante Pazzanese Cardiol, São Paulo

28 - Yeni PG, Hammer SM, Carpenter CCJ et al.

Antiretroviral treatment for adult HIV infection in 2002 - Updated recommendations of the international AIDS Society-USA panel

JAMA - Journal of the American Medical Association 288 (2): 222-235 Jul 102002

Times Cited: 293 USA, Australia, Spain, England, France, Canada, Brazil, Italy (18).

Fac Med, UFRJ, Rio de Janeiro

29 - Pocock SJ, Henderson RA, Rickards AF et al.

Metaanalysis of randomized trials comparing coronary angioplasty with bypass-surgery

Lancet 346 (8984): 1184-1189 Nov 41995

Times Cited: 285 England, USA, Germany, Brazil, Switzerland, Argentina (10).

INCOR, USP, São Paulo

30 - Weiner J, Bagnato VS, Zilio S et al.

Experiments and theory in cold and ultracold collisions

Reviews of Modern Physics 71 (1): 1-85 Jan 1999

Times Cited: 268 Brazil, USA (4). Inst Fisica Sao Carlos, USP

31 - Poulter NR, Chang CL, Farley TMM et al.

Venous thromboembolic disease and combined oral-contraceptives - results of international multicenter case-control study

Lancet 346 (8990): 1575-1582 Dec 161995

Times Cited: 264 Brazil, Chile, Peoples R China, Colombia, England, Germany, Hong Kong, Hungary, Indonesia, Jamaica, Kenya, Mexico, Slovenia, Thailand, Yugoslavia, Zambia,

Zimbabwe (41). Esc Paul Med, UNIFESP, São Paulo

32 - Stein R, Sherrill D, Morgan WJ et al.

Respiratory syncytial virus in early life and risk of wheeze and allergy by age 13 years

Lancet 354 (9178): 541-545 Aug 141999

Times Cited: 264 Brazil, USA (8). Dept Pediatria, PUC RS, Porto Alegre

33 - McKelvie RS, Yusuf S, Pericak D et al.

Comparison of candesartan, enalapril, and their combination in congestive heart failure -

Randomized evaluation of strategies for left ventricular dysfunction (RESOLVD) pilot study

- The RESOLVD pilot study investigators

Circulation 100 (10): 1056-1064 Sep 71999

Times Cited: 257, Brazil, Canada, Italy, USA (14). Inst Dante Pazzanese Cardiol, São Paulo

34 - Gazzinelli RT, Wysocka M, Hieny S et al.

In the absence of endogenous IL-1O, mice acutely infected with Toxoplasma gondii succumb

to a lethal immune response dependent on CD4(+) T cells and accompanied by

overproduction of IL-12, IFN-gamma, and TNF-alpha

Journal of Immunology 157 (2): 798-805 Jul 151996

Times Cited: 253, Brazil, USA, Germany (9). Dept Bioq Imunol, UFMG, Belo Horizonte 
TABLE I (continuation)

\author{
35 - Saitoh T, Bocquet AE, Mizokawa T et al. \\ Electronic-structure of LA1-XSRXMNO3 studied by photoemission and \\ X-ray-absorption spectroscopy \\ Physical Review B 51 (20): 13942-13951 May 151995 \\ Times Cited: 253 Japan, Brazil (8). Lab Nac Luz Sincrotron, Campinas \\ 36 - Rosendaal FR, Doggen CJM, Zivelin A et al. \\ Geographic distribution of the $20210 \mathrm{G}$ to A prothrombin variant \\ Thrombosis and Haemostasis 79 (4): 706-708 Apr 1998 \\ Times Cited: 252 Netherlands, Israel, Brazil, France, USA, Sweden, Austria, Italy, England (12). \\ Ctro Hematol Hemoterapia, FCM, UNICAMP \\ 37 - Nepstad DC, Decarvalho CR, Davidson EA et al. \\ The role of deep roots in the hydrological and carbon cycles of Amazonian forests and pastures \\ Nature 372 (6507): 666-669 Dec 151994 \\ Times Cited: 250 USA, Brazil (10). EMBRAPA, CPATU, Belém

\begin{abstract}
Note: The countries mentioned in the affiliation of the articles and the Brazilian institutions to which the national authors are affiliated are indicated. At the end of the list of countries for each article the number of authors of the study is between brackets.
\end{abstract}

templated in an incipient manner, such as Mathematics (5 articles), Computer Sciences (8 articles), Anthropology (3 articles), Engineering (26 articles), Veterinary Medicine (6 articles), Agriculture (4 articles) and Biophysics (14 articles). These data stress the relevance of carefully handling scientometric indicators. However, it is important to mention that mapping centers of excellence does not significantly differ in the two surveys.

It is also necessary to consider that this survey encompasses a recent period of ten years, drawing an update picture of the most impacting researches. One could wonder about the absence of research groups that were outstanding in decades previous to that addressed in this survey. These groups continue to be acknowledged, but our goal is to obtain a picture the most updated possible, although, however, this demanded a relatively long timeframe (10 years) to obtain consistent data.

The choice of most-cited articles enables different mappings, which other indicators, such as total number of citations or publications of authors or institutions, would render it more difficult. The great number of citations achieved by an author does not indicate necessarily a high impact within a thematic proposal, since these citations can be diluted in a broad set of approaches. This is the case, for example, of researchers using more refined techniques to study a variety of topics. Or simply the case in which a high number of citations is the result from a high number of publications, each with a small number of citations, not individually reflecting a significant impact (Hirsch 2005).

The present study could detect important trends of the recent Brazilian scientific research in the international context.

\section{ARTICLES ON THE AMAZON RAINFOREST}

The dynamics of changes in the Amazon rainforest due to the intervention by mankind, through deforestation for agriculture purposes, timber exploration and forest fires, has lately become a pungent topic. The discussion encompasses geopolitical issues, changes in the ecosystem, sustainable economic exploration, and gains extensive space in the international press. Not surprisingly, the most outstanding scientific journals also open space for articles in this field. Among the 248 HC-ISI articles, 12 were dedicated to this topic (Table II). Seven were in 
collaboration with the United States and four were researches conducted solely with Brazilian affiliation. Three articles were published by Nature and three by Science. These researches tend to corroborate the disastrous consequences of uncontrolled exploration of the rainforest. Nine articles result from studies carried out by institutions from the Northern region of Brazil, eight of which are from the Instituto Nacional de Pesquisa da Amazônia (INPA), located in Manaus. This fact is extremely good news, because it demonstrates the possibility of conducting high level researches, on a topic related to issues of an economically challenged region. INPA is an institution established in 1954 and connected to the Ministry of Science and Technology, where Brazilian and foreign researchers streamed to, attracted by the challenge of understanding the biology from this magnificent rainforest. The articles are very rich in terms of themes. Among these investigators is Philip Fearnside, an American that arrived in Brazil in the 1970's, and is considered one of the greatest international authorities in sustainable development in environments such as the Amazon rainforest. His studies put him in a comfortable position to defend what is called the international carbon market. The wealthy countries, at some point, will have to pay for Brazil to preserve the Forest, says Fearnside: "the capability of absorbing carbon will bring more money than selling soybeans".

Some articles have titles that could have been in newspaper headlines: "Physical and human dimensions of the Amazon deforestation", "Collapse of biomass in fragments of the Amazon rainforest", "Large scale impoverishment in the Amazon rainforest due to timber exploration and forest fires". Other titles show the concern with the dynamics of carbon recycling through photosynthesis, breathing and decomposition, or in deforestation and replanting conditions. Since it is an extremely up-to-date topic, the press that reports statements from politicians, economists and environmentalists, should listen more to scientists, whose studies are published in the most acknowledged journals, with far-reaching repercussion.

\section{ARTICLES ON SURGERY}

Another field that stood out for publishing highly cited ISI articles was surgery, and all articles were related to the cardiovascular subfield (Table III). The great majority were works in multinational networks concerning several types of investigation. The classification of these articles in the field of surgery was very flexible since 12 works were related to research on interventions with angioplasty techniques and use of stents. This is a very strong field in Brazil, particularly in the City of São Paulo, with the participation of Incor (Faculdade de Medicina da USP), Instituto Dante Pazzanese and Hospital Unicor. Another research that stood out was the team from the Hospital Angelina Caron, in Campina Grande do Sul, State of Paraná, coordinated by Randas Batista, who introduced the technique to reduce an enlarged heart by partial left ventriculectomy. This technique had far-reaching repercussion; although it is not a procedure established for end-stage cardiac patients, it led to new research opportunities to improve the intervention. Finally, one work that drew attention was published in 2003 and has already achieved 112 citations. It addresses transendocardial autologous bone marrow cell transplantation in patients with severe chronic ischemic heart failure (article 18, Table III). This study reported a new and relatively successful procedure and has prospects for future studies on transplant of stem cells in this type of condition. The groups from the Hospital Procardíaco and the Universidade Federal do Rio de Janeiro participated in this study.

\section{Oxidative Metabolism and Free Radicals}

This is a very active field in Brazil and a reflex of significant increasingly interest all over the world. More than 20 groups throughout Brazil study the diverse aspects of cellular oxyreduction processes and their effects in changing molecular structures and control cell regulation mechanisms. Table IV shows ten articles on this research line that achieved over 100 citations. Six of these had Brazilian affiliation, no international collaboration and stood out 
TABLE II

Most-cited ISI articles on the Amazon forest.

1 - Nepstad DC, DeCarvalho CR, Davidson EA, et al.

The role of deep roots in the hydrological and carbon cycles of Amazonian forests and pastures Nature 372 (6507): 666-669 Dec 151994

Times Cited: 250 USA, Brazil. EMBRAPA, CPATU, Belém, Pará

2 - Hedges JI, Cowie GL, Richey JE et al.

Origins and processing of organic-matter in the Amazon river as indicated by carbohydrates and amino-acids

Limnology and Oceanography 39 (4): 743-761 Jun 1994

Times Cited: 110 USA, Brazil. INPA, Manaus, Amazonas

3 - Skole DL, Chomentowski WH, Salas WA et al.

Physical and human dimensions of deforestation in Amazonia

Bioscience 44 (5): 314-322 May 1994

Times Cited: 118 USA, Brazil. INPA, Manaus, Amazonas

4 - Fearnside PM

Deforestation in Brazilian Amazonia - The effect of population and land-tenure

AMBIO 22 (8): 537-545 Dec 1993

Times Cited: 114 Brazil. INPA, Manaus, Amazonas

5 - Trumbore SE, Davidson EA, DeCamargo PB et al.

Belowground cycling of carbon in forests and pastures of eastern Amazonia

Global Biogeochemical Cycles 9 (4): 515-528 Dec 1995

Times Cited: 127 USA, Brazil. CENA, ESALQ, USP, São Paulo

6 - Grace J, Lloyd J, McIntyre J et al.

Carbon-dioxide uptake by an undisturbed tropical rain-forest in southwest Amazonia,

1992 to 1993

Science 270 (5237): 778-780 Nov 31995

Times Cited: 200 Scotland, Australia, Brazil, England, USA. Un Nacional de Brasilia,

Lab Ecologia, DF

7 - Lloyd J, Grace J, Miranda AC et al.

A simple calibrated model of Amazon rain-forest productivity based on

leaf biochemical-properties

Plant Cell and Environment 18 (10): 1129-1145 Oct 1995

Times Cited: 103 Australia, Scotland, Brazil, England. Un Nacional de Brasilia,

Lab Ecologia, DF

8 - Laurance WF, Laurance SG, Ferreira LV et al.

Biomass collapse in Amazonian forest fragments

Science 278 (5340): 1117-1118 Nov 71997

Times Cited: 135, Brazil, INPA, Manaus, Amazonas

9 - Laurance WF, Ferreira LV, Rankin-de Merona JM et al.

Rain forest fragmentation and the dynamics of Amazonian tree communities

Ecology 79 (6): 2032-2040 Sep 1998

Times Cited: 110 Brazil, INPA, Manaus, Amazonas 
TABLE II (continuation)

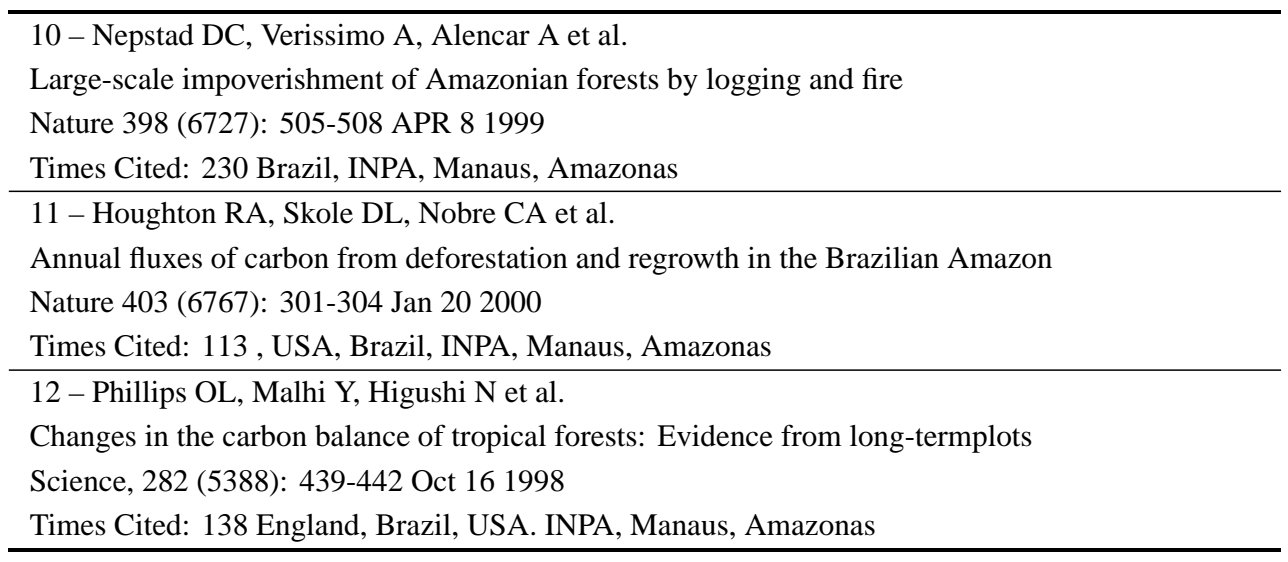

The countries mentioned in the affiliation of the articles and the Brazilian institutions to which the national authors are affiliated are indicated.

in this field among the most-cited articles. A work by a group of the Faculdade de Ciências Médicas da UNICAMP, coordinated by Aníbal Vercesi, made success with studies on changes by oxidation of mitochondrial membrane proteins (a cell organelle responsible for oxidative metabolism) that result in cell death (articles 3, 4, 7, 9 and 10, Table IV). The studies also addressed the role of calcium ions in this process. The group was responsible for five articles.

The group of Ohara Augusto, from the Department of Biochemistry of the Instituto de Química da USP, had a successful partnership with the group of Rafael Radi, from Uruguay. This collaboration was one of the few carried out exclusively between two Latin American countries, as already mentioned (Packer and Meneghini 2006), and it is represented by three works in Table IV (articles 1, 2 and 8). These articles resulted in a work in 1999 (article 8), which reported the formation of a carbonate radical, a chemical species not identified in live organisms at that time. The group of Augusto is still successfully investigating the issue.

\section{Chemical Catalysis}

Chemical catalysis is one the most advanced topics in modern chemistry. Its results reverberate in basic and technological chemistry and resound in
Biochemistry. Seven works had far-reaching repercussion as demonstrated in Table V. Five of these articles were written by one group from the Universidade Federal do Rio Grande do Sul, known as the "Catalysis Group". Coordinated by Jairton Dupont and Roberto F. de Souza, the group has studied biphasic organometallic catalysis in ionic fluids, aiming to produce high synthesis yields at room temperature and in conditions to preserve the environment. Their results can be assessed by the high number of citations related to their articles.

\section{GenOMICS}

Genome sequence is a research field of the end of the $20^{\text {th }}$ century and beginning of the $21^{\text {st }}$ century. Brazil has joined this exclusive group in high style by performing the genome sequence of the phytopatogenic bacterium Xylella fastidiosa. This study was published as the cover article in Nature, in 2000. The topic was extensively covered in the lay press both in Brazil and abroad.

This effort was put forth by the State of São Paulo, with financial and logistic support of the FAPESP, which established a real headquarter to make this project feasible in multiple aspects. Scientific and organizational competence was required for its success. A genome sequence network was as- 
TABLE III

Most-cited ISI articles on cardiac surgery.

1 - Ellis SG, DaSilva ER, Heyndrickx G, et al.

Randomized comparison of rescue angioplasty with conservative management of patients with early failure of thrombolysis for acute anterior myocardial-infarction

Circulation 90 (5): 2280-2284 Part 1 Nov 1994

Times Cited: 183, Brazil, UNICOR Hosp, São Paulo

2 - Hueb WA, Bellotti G, DeOliveira SA et al.

The medicine, angioplasty or surgery study (mass) - A Prospective, randomized trial of medical therapy, balloon angioplasty or bypass-surgery for single proximal left anterior descending artery stenoses

Journal of the American College of Cardiology 26 (7): 1600-1605 Dec 1995

Times Cited: 115 Brazil, Incor, Fac Med USP

3 - Pocock SJ, Henderson RA, Rickards AF et al.

Metaanalysis of randomized trials comparing coronary angioplasty with bypass-surgery

Lancet 346 (8984): 1184-1189 Nov 41995

Times Cited: 285 England, USA, Germany, Brazil, Switzerland, Argentina. Incor, Fac Med USP

4 - Batista RJV, Santos JLV, Takeshita N et al.

Partial left ventriculectomy to improve left ventricular function in end-stage heart disease

Journal of Cardiac Surgery 11 (2): 96-97 Mar-Apr 1996

Times Cited: 235, Brazil. Hosp Caron, Campina G Sul, Pr

5 - Buffolo E, deAndrade JCS, Branco JNR et al.

Coronary artery bypass grafting without cardiopulmonary bypass

Annals of Thoracic Surgery 61 (1): 63-66 Jan 1996

Times Cited: 336, BRAZIL. Esc Paul Med, UNIFESP

6 - Weaver WD, Simes RJ, Betriu A et al.

Comparison of primary coronary angioplasty and intravenous thrombolytic therapy for acute myocardial infarction - A quantitative review

JAMA - Journal of the American Medical Association 278 (23): 2093-2098 Dec 171997

Times Cited: 387 USA, Australia, Spain, Netherlands, Argentina, Brazil, Italy. UNICOR, SP

7 - Batista RJV, Verde J, Nery P, et al.

Partial left ventriculectomy to treat end-stage heart disease

Annals of Thoracic Surgery 64 (3): 634-638 Sep 1997

Times Cited: 160, Brazil, USA. Hosp Caraon, Campina G Sul, Pr

8 - Serrano CV, Ramires JAF, Venturinelli M et al.

Coronary angioplasty results in leukocyte and platelet activation with adhesion molecule

expression - Evidence of inflammatory responses in coronary angioplasty

Journal of the American College of Cardiology 29 (6): 1276-1283 May 1997

Times Cited: 109, Brazil, USA. Incor, Fac Med, USP

9 - Serruys PW, van Hout B, Bonnier H et al.

Randomised comparison of implantation of heparin-coated stents with balloon angioplasty

in selected patients with coronary artery disease (Benestent II)

Lancet 352 (9129): 673-681 Aug 291998

Times Cited: 294 Netherlands, Belgium, Spain, Brazil, Italy, Portugal, New Zealand, Sweden,

France, Germany. Inst Dante Pazzanese, SP 


\section{TABLE III (continuation)}

10 - Yusuf S, Flather M, Pogue J et al.

Variations between countries in invasive cardiac procedures and outcomes in patients with suspected unstable angina or myocardial infarction without initial ST elevation Lancet 352 (9127): 507-514 Aug 151998

Times Cited: 189 Canada, England, Australia, Brazil, USA, Hungary, Poland, Scotland.

Inst Dante Pazzanese, SP

11 - Stone GW, Brodie BR, Griffin JJ et al.

Prospective, multicenter study of the safety and feasibility of primary stenting in acute myocardial infarction: In-hospital and 30-day results of the PAMI stent pilot trial Journal of the American College of Cardiology 31 (1): 23-30 Jan 1998

Times Cited: 162 USA, France, Brazil. Hosp Santa Casa Miseric, Curitiba, Pr

12 - Wholey MH, Wholey M, Mathias K et al.

Global experience in cervical carotid artery stent placement

Catheterization and Cardiovascular Interventions 50 (2): 160-167 Jun 2000

Times Cited: 163 USA, Germany, France, England, Spain, China, Brazil, França, Singapore,

Argentina, Colombia, Czech Republic, Japan. Inst Dante Pazzanese, SP

13 - Sousa JE, Costa MA, Abizaid AC et al.

Sustained suppression of neointimal proliferation by sirolimus-eluting stents -

One-year angiographic and intravascular ultrasound follow-up

Circulation 104 (17): 2007-2011 Oct 232001

Times Cited: 217 Brazil, Netherlands, USA. Inst Dante Pazzanese, SP

14 - Serruys PW, Unger F, Sousa JE et al.

Comparison of coronary-artery bypass surgery and stenting for the treatment of multivessel disease.

New England Journal of Medicine 344 (15): 1117-1124 Apr 122001

Times Cited: 198 Netherlands, Austria, Brazil, England. Inst Dante Pazzanese, SP

15 - Sousa JE, Costa MA, Abizaid A et al.

Lack of neointimal proliferation after implantation of sirolimus-coated stents in human coronary arteries - A quantitative coronary angiography and three-dimensional intravascular

ultrasound study

Circulation 103 (2): 192-195 Jan 162001

Times Cited: 242 Brazil, USA, Netherlands. Inst Dante Pazzanese, SP

16 - Serruys PWJC, de Feyter P, Macaya C et al.

Fluvastatin for prevention of cardiac events following successful first percutaneous coronary intervention - A randomized controlled trial

JAMA - Journal of the American Medical Association 287 (24): 3215-3222 Jun 262002

Times Cited: 119 Netherlands, Spain, France, Belgium, Italy, Brazil, England, Canada,

Switzerland, Germany. Inst Danate Pazzanese, SP

17 - Morice M, Serruys PW, Sousa JE et al.

A randomized comparison of a sirolimus-eluting stent with a standard stent for

coronary revascularization

New England Journal of Medicine 346 (23): 1773-1780 Jun 62002

Times Cited: 590 Brazil, France, Netherlands, Mexico, Italy, Germany, Hungary, USA.

Incor, Fac Med, USP 
TABLE III (continuation)

\author{
18 - Perin EC, Dohmann HFR, Borojevic R et al. \\ Transendocardial, autologous bone marrow cell transplantation for severe, chronic \\ ischemic heart failure \\ Circulation 107 (18): 2294-2302 May 132003 \\ Times Cited: 112, USA, BRAZIL. Hospital Procardiaco, Rio de Jáneiro, Brazil; Federal \\ University, Rio de Janeiro, Brazil; and Brazilian Millennium Institute for \\ Tissue Bioengineering \\ The countries mentioned in the affiliation of the articles and the Brazilian institutions to which the national \\ authors are affiliated are indicated.
}

sembled, named ONSA (Organization for Nucleotide Sequence Analysis) and it has been in charge of many genome sequence projects that followed the study on Xyllela. Although recent, the articles have already achieved a high number of citations, as displayed in Table VI.

The network studies had multiple authors but are not multinational works. The genome sequence of Xyllela was assisted by one researcher from France and another from Germany, but it was the result of the work carried out by Brazilian leaders and over one hundred Brazilian investigators. It could be said it was autochthonous.

Beside these articles, many other genome sequence projects were initiated in Brazil. A healthy competition was established in programs of the Ministry of Sciences and Technology and agencies from other states; since then many genomes have been sequenced. In terms of citations, these other articles will have to wait for a while, considering the results were published very recently.

It is too early to conclude if this was the best manner to achieve proficiency in molecular biology in Brazil. However, it should be acknowledged that there was a fundamental know-how gain to organize research network programs at national level, which is already influencing other fields.

\section{NEUROCIENCES}

Some strong leaders stand out in neurociences in Brazil. Sixteen articles are shown in Table VII, with over 100 citations.
Three groups are particularly worth mentioning in Behavioral Pharmacology. Frederico Graeff, from the Faculdade de Filosofia Ciências e Letras da USP de Ribeirão Preto, aimed to understand the effect of anxiogenic and anxiolytic drugs in animal behavior using rats as the experimental model (articles 1,2). Studying anxiety and stress, the group of André Ramos, from the Departamento de Biologia Celular, Embriologia e Genética - UFSC, has investigated an interesting issue, that is, the genetic component of this behavior (articles 7,8). Finally, a highly productive group, with several articles often cited is coordinated by Ivan Izquierdo, from the Departamento de Biochemistry da UFRGS (articles 3,6 ). Izquierdo investigates memory mechanisms with animal experimental models in order to pharmacologically map the memorization process paths. Izquierdo has a long-term collaboration with J. Medina, from Argentina. The great majority of articles are signed by these two scientists and comprises a rare fruitful collaboration between two Latin American countries, like another already mentioned between Brazil and Uruguay.

Xavier Albuquerque is a pharmacologist who investigates the synaptic transmission in neurons. His career was carved out and became successful in a center he founded at the University of Maryland, in the United States. In the 1980's he established a molecular pharmacology center at the Instituto de Biofísica Carlos Chagas Filho - UFRJ. Later, he joined the Instituto de Ciências Biomédicas, Departamento de Farmacologia Básica e Clínica - UFRJ. 
TABLE IV

Most-cited ISI articles on oxidative metabolism and free radicals.

1 - Gatti RM, Radi R, Augusto O

Peroxynitrite-mediated oxidation of albumin to the protein-thiyl free-radical

FEBS Letters 348 (3): 287-290 Jul 181994

Times Cited: 102 Brazil, Uruguay. Depto Bioquimica, Inst Quimica, USP

2 - Augusto O, Gatti RM, Radi R

Spin-trapping studies of peroxynitrite decomposition and of 3-morpholinosydnonimine

n-ethylcarbamide autooxidation - direct evidence for metal-independent formation

of free-radical intermediates

Archives of Biochemistry and Biophysics 310 (1): 118-125 APR 1994

Times Cited: 103 Brazil, Uruguay, Depto Bioquimica, Inst Quimica, USP

3 - Vercesi AE, Martins IS, Silva MAP et al.

Pumping plants, Nature 375 (6526): 24-24 May 41995

Times Cited: 112 Brazil. Depto Bioquimica, Inst Biologia, UNICAMP. Depto Bioquimica,

Inst Quimica, USP

4 - Castilho RF, Kowaltowski AJ, Meinicke AR, et al.

Permeabilization of the inner mitochondrial-membrane by $\mathrm{Ca} 2+$ ions is stimulated by

t-butyl hydroperoxide and mediated by reactive oxygen species generated by mitochondria

Free Radical Biology and Medicine 18 (3): 479-486 Mar 1995

Times Cited: 112, Brazil. Depto Bioquim, Inst Biologia, UNICAMP. Depto Bioquim, Inst Quimica, USP

5 - Monteiro HP, Stern A

Redox modulation of tyrosine phosphorylation-dependent signal transduction pathways

Free Radical Biology and Medicine 21 (3): 323-333 1996

Times Cited: 133, Brazil, Fdn Prosangue, Hemocentro, São Paulo

6 - Meneghini R

Iron homeostasis, oxidative stress, and DNA damage

Free Radical Biology and Medicine 23 (5): 783-792 1997

Times Cited: 140, Brazil. Depto Bioquimica, Inst Quimica, USP

7 - Jezek P, Engstova H, Zackova M, et al.

Fatty acid cycling mechanism and mitochondrial uncoupling proteins

Biochimica et Biophysica Acta-Bioenergetics 1365 (1-2): 319-327 Jun 101998

Times Cited: 109 Czech Republic, Brazil. Depto Patol Clin, Fac Ciencias Medicas, UNICAMP

8 - Bonini MG, Radi R, Ferrer-Sueta G, et al.

Direct EPR detection of the carbonate radical anion produced from peroxynitrite and carbon dioxide

Journal of Biological Chemistry 274 (16): 10802-10806 Apr 161999

Times Cited: 101 Brazil, Uruguay. Depto Bioquim, Inst Quimica, USP

9 - Kowaltowski AJ, Vercesi AE

Mitochondrial damage induced by conditions of oxidative stress

Free Radical Biology and Medicine 26 (3-4): 463-471 Feb 1999

Times Cited: 182, Brazil, Depto Patol Clin, Fac Ciencias Medicas, UNICAMP

10 - Kowaltowski AJ, Castilho RF, Vercesi AE

Mitochondrial permeability transition and oxidative stress

FEBS Letters 495 (1-2): 12-15 Apr 202001

Times Cited: 114 Brazil. Depto Patol Clin, Fac Ciencias Medicas, UNICAMP

The countries mentioned in the affiliation of the articles and the Brazilian institutions to which the national authors are affiliated are indicated. 
TABLE V

Most-cited ISI articles on chemical catalysis.

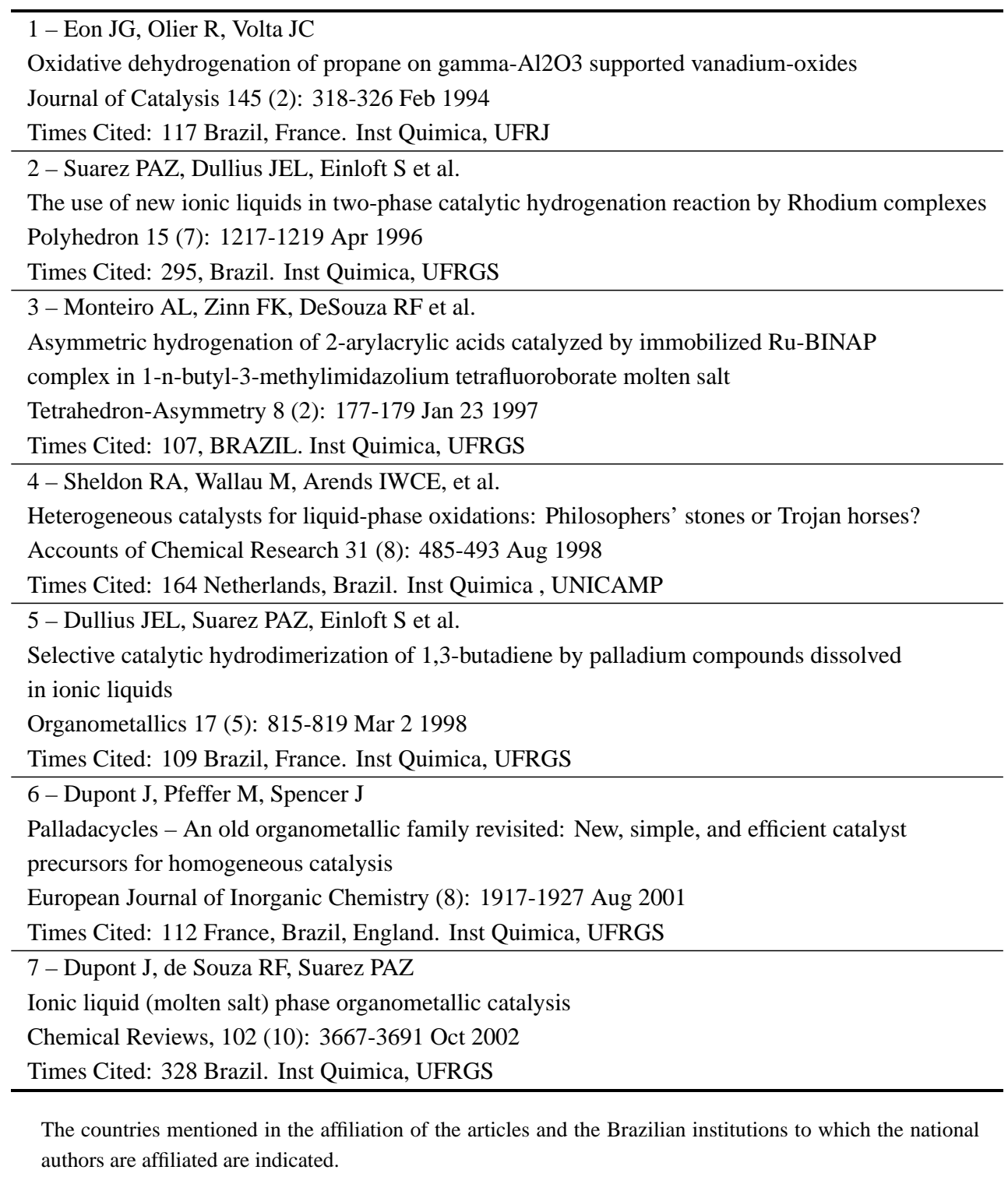

From then on, he has simultaneously worked at the University of Maryland and at the UFRJ and indicates both affiliations in his articles. His works are strongly focused on the biophysical aspects of the synaptic process, investigating the behavior of ionic membrane channels in relation to drugs (articles 9-14).

One of the authors of article 15, in Table VII, is Brazilian, but the study was conducted in the laboratory of Miguel Nicolelis, of the University of Duke, United States. Nicolelis is Brazilian and internationally acknowledged for his works about sensorimotor connections. He obtained significant results by implanting chips in the brain of a monkey, who enabled him to control a robotic arm. Nicolelis is currently involved in establishing a center of Neu- 
TABLE VI

Most-cited ISI articles on genomics.

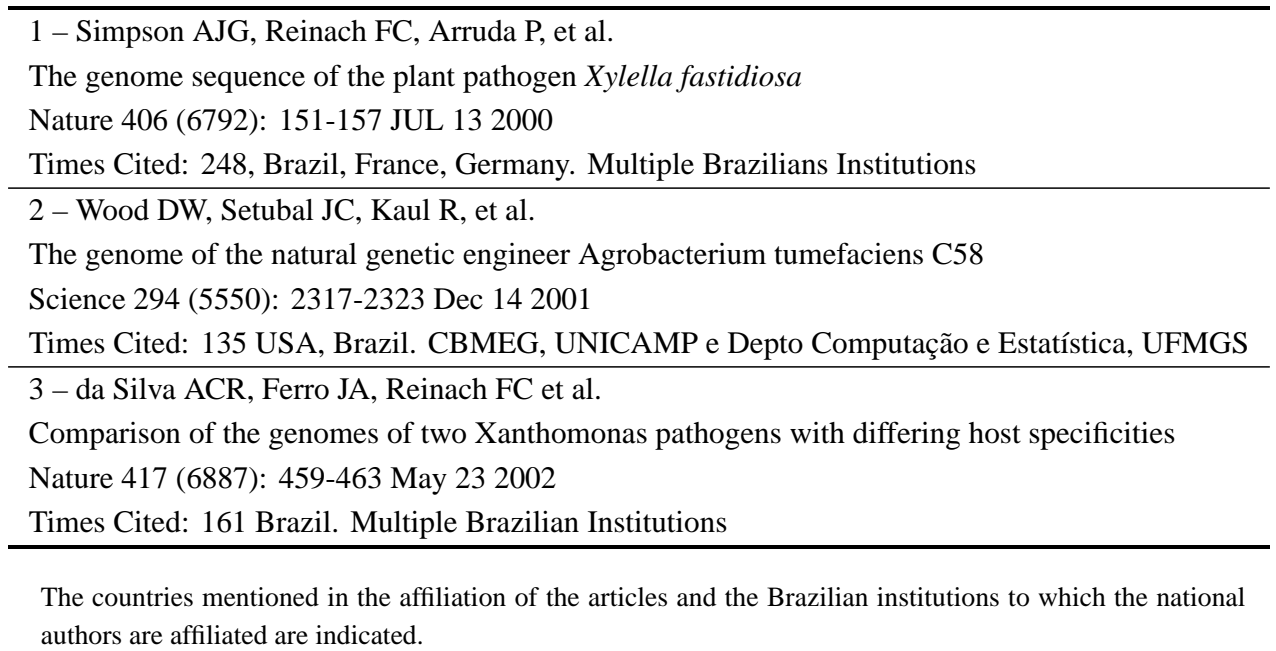

rosciences in Natal, Rio Grande do Norte.

Both Albuquerque and Nicolelis were graduate students of César Timo-Iaria, a researcher at the USP and a pioneer in neurosciences in Brazil, who passed away in June 27, 2005.

\section{PHYSICS OF PARTICLES}

This field requires large and very expensive pieces of equipment, particularly the big particle and ion accelerators, which are not available in Brazil and used for study experiments on collisions. Therefore, and also due to the need to extensively collect and prepare data, international networks with many authors started to demonstrate advances in this field. Table VIII displays 13 articles related to this field; seven $(1,4,5,6,7,8,9)$ are from a network with Brazilian participants who are affiliated to the Instituto de Física - USP and four articles (10-13) are from another network, of which the Brazilian participants are affiliated to the Centro Brasileiro de Pesquisas Físicas do Rio de Janeiro. The first network achieved 945 citations. The mean number of countries per article of the seven articles is 9.4, and the mean number of authors per article is 154 . One article had 403 authors (article 6). It should be mentioned that the seven articles were published in Physics Review Letters, which is considered the best journal of Physics. More recently, these studies have used a powerful ion accelerator - the Relativistic Heavy Ion Collider (RHIC), of the Brookhaven National Laboratory, United States. Hundreds of physicists from all over the world have used the RHIC to study how the universe could have been moments after its creation. The RHIC has two gold ion beams in opposite directions in a subatomic collision. The other network uses the Large ElectronPositron collider of the CERN, in France. It is an accelerator which makes collisions of electrons and positrons in a $27-\mathrm{km}$ circumference ring. When the beam of electrons and positrons collide, some of them disappear and create, during a second fraction, high energy explosions that are reminiscent for the newly created universe, providing data that complement those from the RHIC. The four works were cited 575 times, have an average of 13.5 countries/article and 456 authors/article, and, in one case, it achieved 593 authors (article 12).

Once again, the comments about credits of researchers and institutions participating in the articles of those giant networks, by means of personal and institutional citation rates and impact factors of the journals, are valid. 


\section{TABLE VII}

\section{Most-cited ISI articles on neurosciences.}

1 - Cruz APM, Frei F, Graeff FG

Ethopharmacological analysis of rat behavior on the elevated plus-maze

Pharmacology Biochemistry and Behavior 49 (1): 171-176 Sep 1994

Times Cited: 223 Brazil. Univ São Paulo, FFCL Rib Pret; Univ Est Paul, FCLA, Assis

2 - Graeff FG, Guimaraes FS, DeAndrade TGCS et al.

Role of 5-HT in stress, anxiety, and depression

Pharmacology Biochemistry and Behavior 54 (1): 129-141 May 1996

Times Cited: 218, Brazil, England. Univ São Paulo, FFCL Rib Pret

3 - Izquierdo I, Medina JH

Correlation between the pharmacology of long-term potentiation and the pharmacology of memory

Neurobiology of Learning and Memory 63 (1): 19-32 Jan 1995

Times Cited: 100, Brazil, Argentina. UFRGS, Inst Bioc, Dept Bioquim, Ctr Memoria

4 - Izquierdo I, Medina JH

Memory formation: The sequence of biochemical events in the hippocampus and its connection

to activity in other brain structures

Neurobiology of Learning and Memory 68 (3): 285-316 Nov 1997

Times Cited: 234, Brazil, Argentina. UFRGS, Inst Bioc, Dept Bioquim, Ctr Memoria

5 - Izquierdo I, Quillfeldt JA, Zanatta MS et al.

Sequential role of hippocampus and amygdala, entorhinal cortex and parietal cortex in formation

and retrieval of memory for inhibitory avoidance in rats

European Journal of Neuroscience 9 (4): 786-793 Apr 1997

Times Cited: 107, Brazil, Argentina. UFRGS, Inst Bioc, Dept Bioquim, Ctr Memoria

6 - Bernabeu R, Bevilaqua L, Ardenghi P et al.

Involvement of hippocampal cAMP/cAMP-dependent protein kinase signaling pathways in a late

memory consolidation phase of aversively motivated learning in rats

Proceedings of the National Academy of Sciences of the United States of America 94 (13):

7041-7046 Jun 241997

Times Cited: 150, Argentina, Brazil. UFRGS, Inst Bioc, Dept Bioquim, Ctr Memoria

7 - Ramos A, Berton O, Mormede P et al.

A multiple-test study of anxiety-related behaviours in six inbred rat strains

Behavioural Brain Research 85 (1): 57-69 Apr 1997

Times Cited: 127, France, Brazil. Dept Biol Cel, Embriol Genet, Univ Fed S Catarina.

8 - Ramos A, Mormede P

Stress and emotionality: a multidimensional and genetic approach

Neuroscience and Biobehavioral Reviews 22 (1): 33-57 Jan 1998

Times Cited: 117 France, Brazil. Dept Biol Cel, Embriol Genet, Univ Fed S Catarina

9 - Castro NG, Albuquerque EX

Alpha-bungarotoxin-sensitive hippocampal nicotinic receptor-channel has a high-calcium permeability

Biophysical Journal 68 (2): 516-524 Feb 1995

Times Cited: 114, USA, Brazil. Fed Univ Rio de Janeiro, Inst Biofis, Farmacol Molec Lab

10 - Albuquerque EX, Alkondon M, Pereira EFR et al.

Properties of neuronal nicotinic acetylcholine receptors: Pharmacological characterization

and modulation of synaptic function

Journal of Pharmacology and Experimental Therapeutics 280 (3): 1117-1136 Mar 1997

Times Cited: 206, USA, Brazil, Germany. Fed Univ Rio de Janeiro, Inst Biofis, Farmacol Molec Lab 
TABLE VII (continuation)

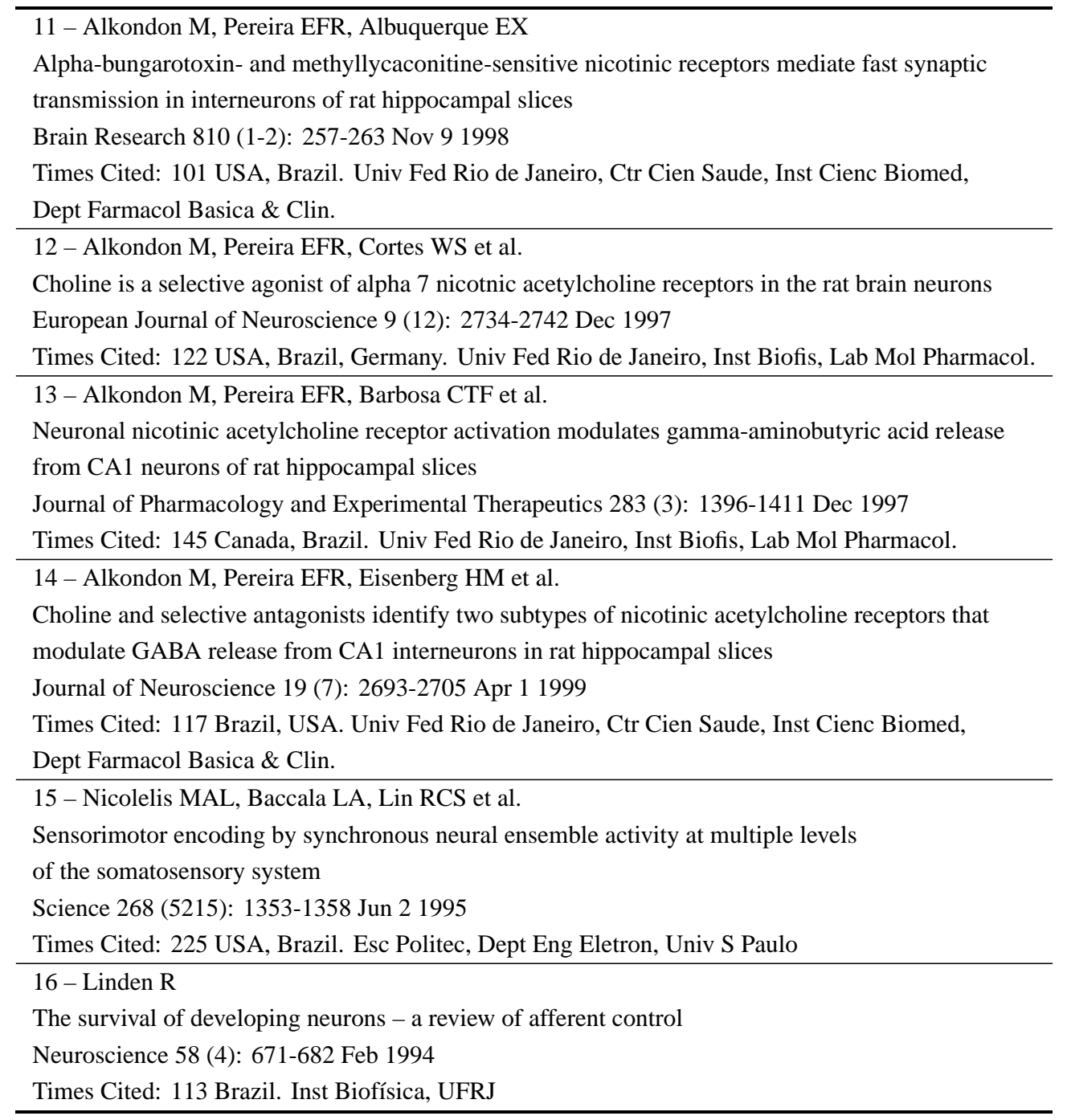

The countries mentioned in the affiliation of the articles and the Brazilian institutions to which the national authors are affiliated are indicated.

\section{QUANTUM PHYSICS}

Two groups excel in Quantum Physics in Brazil and both are located in Rio de Janeiro - one coordinated by Constantino Tsallis, from the Centro Brasileiro de Pesquisas Físicas and another by Luis Davidovich, from the Departamento de Física - UFRJ (Table IX). Tsallis works with theoretical physics of quantum mechanics and statistical mechanics. His works are very often cited (articles
1-5) and internationally acknowledged due to the approaches that have been named after him, Tsallis entropy and Tsallis statistics. Davidovich belongs to the more experimental segment (articles 6,7) and was previously supervised by Moyses Nussenzveig, a Brazilian physicist, at the University of Rochester, United States. Today Nussenzveig works at the Centro Brasileiro de Pesquisas Físicas. Table IX has something curious - it shows the only article (number 4) among 248 included in this survey that was 
TABLE VIII

Most-cited ISI articles on physics of particles.

1 - Barrette J, Bellwied R, Bennett S et al.

Observation of anisotropic event shapes and transverse flow in ultrarelativistic AU+AU collisions

Physical Review Letters 73 (19): 2532-2535 Nov 71994

Times Cited: 105 USA, Germany, Brazil. Inst Física USP

2 - Abachi S, Abbott B, Abolins M et al.

Search for the top-quark in $\mathrm{P}(\mathrm{P})$ over-bar collisions at root-S=1.8 TEV

Physical Review Letters 72 (14): 2138-2142 Apr 41994

Times Cited: 111 USA, Colombia, Brazil, Mexico, Russia, France, India.

Ctr Brasileiro Pesquisas Fis, Rio de Janeiro

3 - Weiner J, Bagnato VS, Zilio S et al.

Experiments and theory in cold and ultracold collisions

Reviews of Modern Physics 71 (1): 1-85 Jan 1999

Times Cited: 268 Brazil, USA. Inst Física São Carlos, USP

4 - Adler C, Ahammed Z, Allgower C et al.

Pion interferometry of root $\mathrm{s}(\mathrm{NN})=130 \mathrm{GeV} \mathrm{Au}+\mathrm{Au}$ collisions at RHIC

Physical Review Letters 87 (8): Art. No. 082301 AUG 202001

Times Cited: 103 Germany, USA, England, Russia, France, Brazil, Poland. Inst Física USP

5 - Adcox K, Adler SS, Ajitanand NN et al.

Centrality dependence of charged particle multiplicity in Au-Au collisions at $\operatorname{root}(\mathrm{S}) \mathrm{NN}=130 \mathrm{GeV}$

Physical Review Letters 86 (16): 3500-3505 Apr 162001

Times Cited: 143 USA, Taiwan, India, China, Japan, Russia, South Korea, Sweden, Canada,

Germany, Brazil, France, Israel, Hungary. Inst Física USP

6 - Ackermann $\mathrm{KH}$, Adams N, Adler C et al.

Elliptic flow in Au plus Au collisions at root $s(\mathrm{NN})=130 \mathrm{GeV}$

Physical Review Letters 86 (3): 402-407 Jan 152001

Times Cited: 191 Germany, USA, England, Russia, France, Brazil, Poland. Inst Física USP

8 - Adcox K, Adler SS, Ajitanand NN et al.

Centrality dependence of pi(+/-), K-+/-, P, and (p)over-bar production from root(NN)-N-S = $130 \mathrm{GeV}$

$\mathrm{Au}+\mathrm{Au}$ collisions at $\mathrm{RHIC}$

Physical Review Letters 88 (24): Art. No. 242301 Jun 172002

Times Cited: 106 USA, Taiwan, India, China, Japan, Russia, South Korea, Sweden, Canada,

Germany, Brazil, France, Israel, Hungary. Inst Física USP

9 - Adcox K, Adler SS, Ajitanand NN et al.

Suppression of hadrons with large transverse momentum in central $\mathrm{Au}+\mathrm{Au}$ collisions at

$\operatorname{root} \mathrm{s}(\mathrm{NN})=130 \mathrm{GeV}$

Physical Review Letters 88 (2): Art. No. 022301 Jan 142002

Times Cited: 184, Brazil, USA, Taiwan, India, China, Japan, Russia, South Korea, Sweden, Canada, Germany, France, Israel, Hungary. Inst Física USP

10 - Abachi S, Abbott B, Abolins M et al.

Search for the top-quark in $\mathrm{P}(\mathrm{P})$ over-bar collisions at root-S=1.8 TEV

Physical Review Letters 72 (14): 2138-2142 Apr 41994

Times Cited: 111 USA, Colombia, Brazil, Mexico, Russia, France, India. Ctr Brasileiro Pesquisas Fis,

Rio de Janeiro 


\section{TABLE VIII (continuation)}

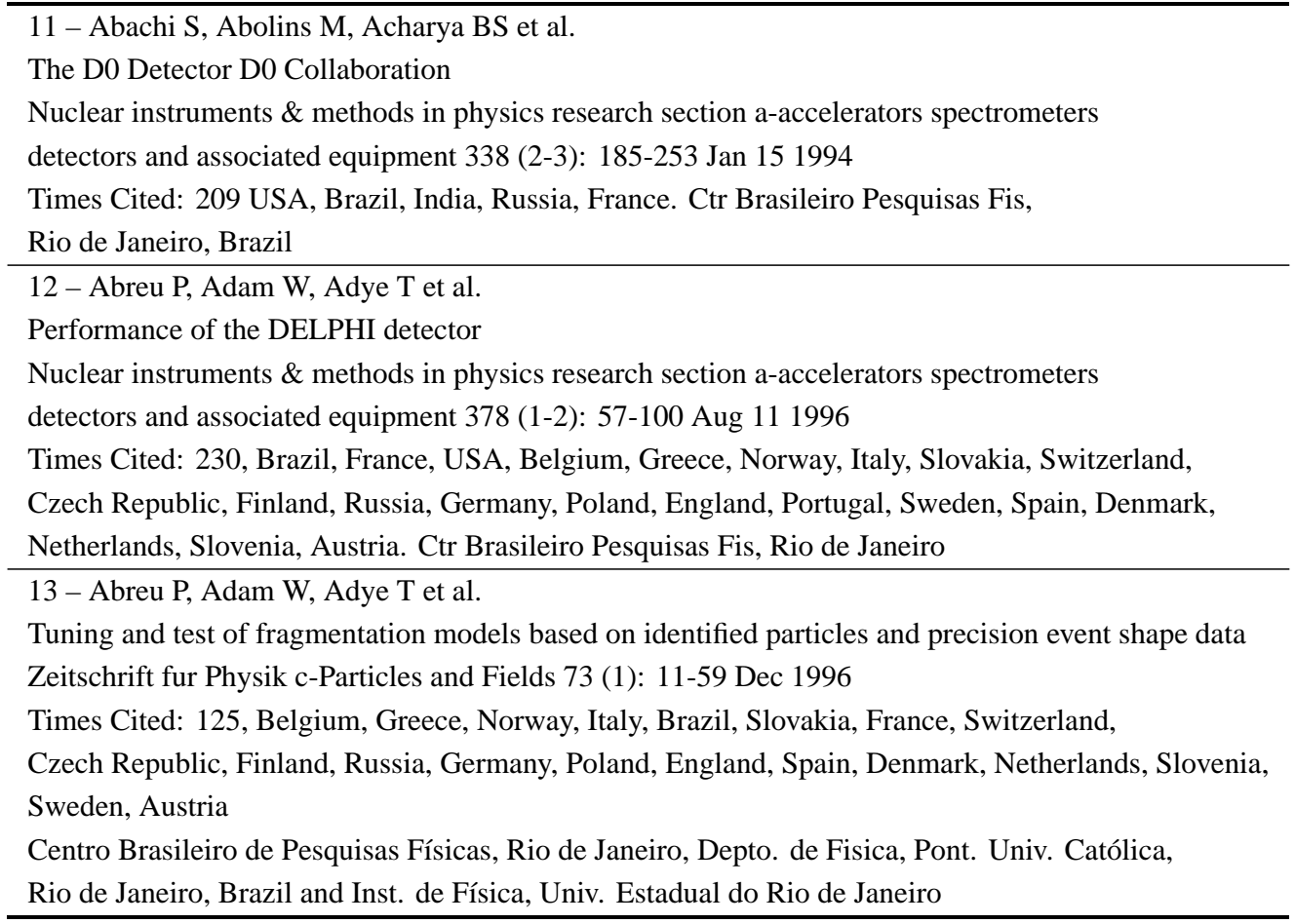

The countries mentioned in the affiliation of the articles and the Brazilian institutions to which the national authors are affiliated are indicated.

published in a national journal - the Brazilian Journal of Physics. This fact demonstrates that Brazilian researchers who are usual contributors to the main stream literature can sporadically submit articles to national journals, and help to enhance their international visibility.

\section{HuMAN Genetics}

Fourteen articles of human genetics achieved farreaching repercussion from 1994 to 2003 and the majority was on mutation related to human hereditary diseases (Table X). In particular, the studies by Mayana Zates and Maria Rita Passos Bueno and their team, in international collaboration with researchers from France, United States, England, Italy and Israel (articles 3, 5, 7 and 8), demonstrated the genes involved in a type of human muscular dystrophy, which is hereditary, autossomal and recessive. These findings are very important for ge- netic diagnosis and counseling, since the mutated genes may be carried by potential healthy parents for it is a recessive disease (the father and the mother must present the mutation). Moreover, the outcome enables a better understanding of the genesis of the disease and may be the path to find drugs and the cure of the condition.

The Unidade de Endocrinologia Genética da Faculdade de Medicina da USP also contributed with two articles on a genetic disease - a type of pseudohermaphroditism (articles 1 and 4), which were published abroad, but with the affiliation of two Brazilian authors from the unit.

\section{Microbial Infectious Diseases}

The landmark of the beginning of Brazilian sciences took place in Rio de Janeiro, in the beginning of the last century, when Oswaldo Cruz, a physician and researcher coordinated and encouraged micro- 
TABLE IX

Most-cited ISI articles on quantum physics.

1 - Tsallis C, Levy SVF, Souza AMC et al.

Statistical-mechanical foundation of the ubiquity of Levy dISTributions in nature

Physical Review Letters 75 (20): 3589-3593 Nov 131995

Times Cited: 226 USA, Brazil, France. Ctr Brasileiro Pesquisas Fis, Rio de Janeiro

2 - Tsallis C, Bukman DJ

Anomalous diffusion in the presence of external forces: Exact time-dependent solutions and

their thermostatistical basis

Physical Review E 54 (3): R2197-R2200 Sep 1996

Times Cited: 152, Brazil, USA. Ctr Brasileiro Pesquisas Fis, Rio de Janeiro

3 - Lyra ML, Tsallis C

Nonextensivity and multifractality in low-dimensional dissipative systems

Physical Review Letters 80 (1): 53-56 Jan 51998

Times Cited: 186 Brazil

Univ Fed Alagoas, Dept Fis, Maceió; Ctr Brasileiro Pesquisas Fis, Rio de Janeiro

4 - Tsallis C

Nonextensive statistics: Theoretical, experimental and computational evidences and connections

Brazilian Journal of Physics 29 (1): 1-35 Mar 1999

Times Cited: 196 Brazil. Ctr Brasileiro Pesquisas Fis, Rio de Janeiro

5 - Tsallis C, Mendes RS, Plastino AR

The role of constraints within generalized nonextensive statistics

Physica A 261 (3-4): 534-554 Dec 151998

Times Cited: 308 Brazil, Denmark, Argentina. Ctr Brasileiro Pesquisas Fis 150, Rio de Janeiro,

Dep Fis, Univ Est Maringa

6 - Davidovich L, Zagury N, Brune M et al.

Teleportation of an atomic state between 2 cavities using nonlocal microwave fields

Physical Review A 50 (2): R895-R898 Part A Aug 1994

Times Cited: 113 France, Brazil. PUC, Dept Fis, Rio de Janeiro

7 - Davidovich L, Brune M, Raimond JM et al.

Mesoscopic quantum coherences in cavity QED: Preparation and decoherence monitoring schemes

Physical Review A 53 (3): 1295-1309 Mar 1996

Times Cited: 146 Brazil, France. Inst Fis, UFRJ, Rio de Janeiro

The countries mentioned in the affiliation of the articles and the Brazilian institutions to which the national authors are affiliated are indicated.

biological studies of parasitary diseases. The legacy of Oswaldo Cruz still yields fruits; thus it is not surprising that Brazilian investigations about microbial infectious diseases continue to reverberate. In the context of contemporary sciences, this clearly implies in studies of molecular immunology, such as those in Table XI.

Three institutions are outstanding in this field
- Departamento de Bioquímica e Imunologia UFMG (articles 1-4), the Instituto Oswaldo Cruz do Rio de Janeiro (articles 9-12) and the Faculdade de Medicina da USP in Ribeirão Preto (articles 3, 5, 7). In particular, the article 2, by Ricardo Gazzinelli from the UFMG, reporting about the importance of a balance in the production of different cytokines (proteins that establish the communication among 
TABLE X

Most-cited ISI articles on human genetics.

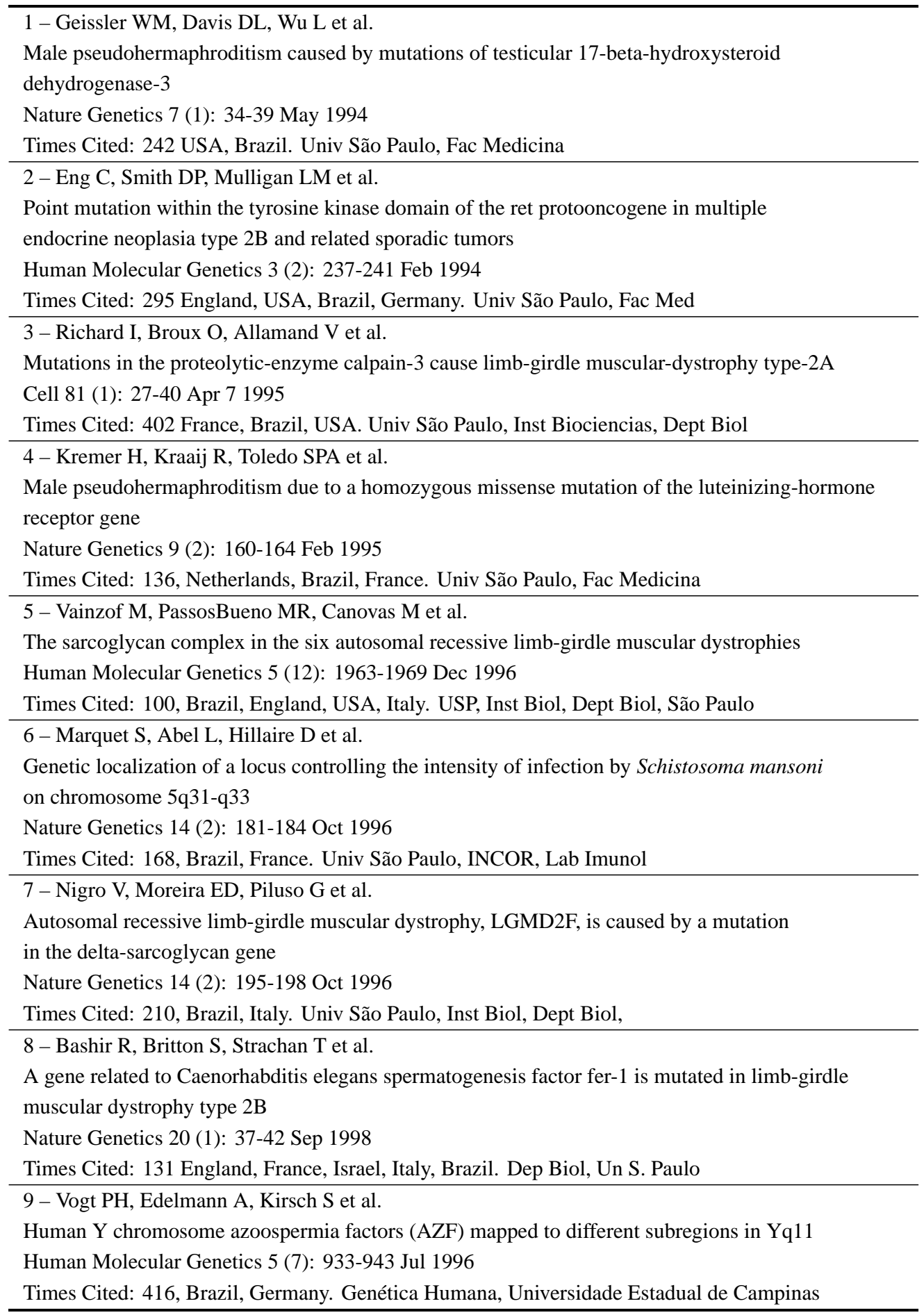


TABLE X (continuation)

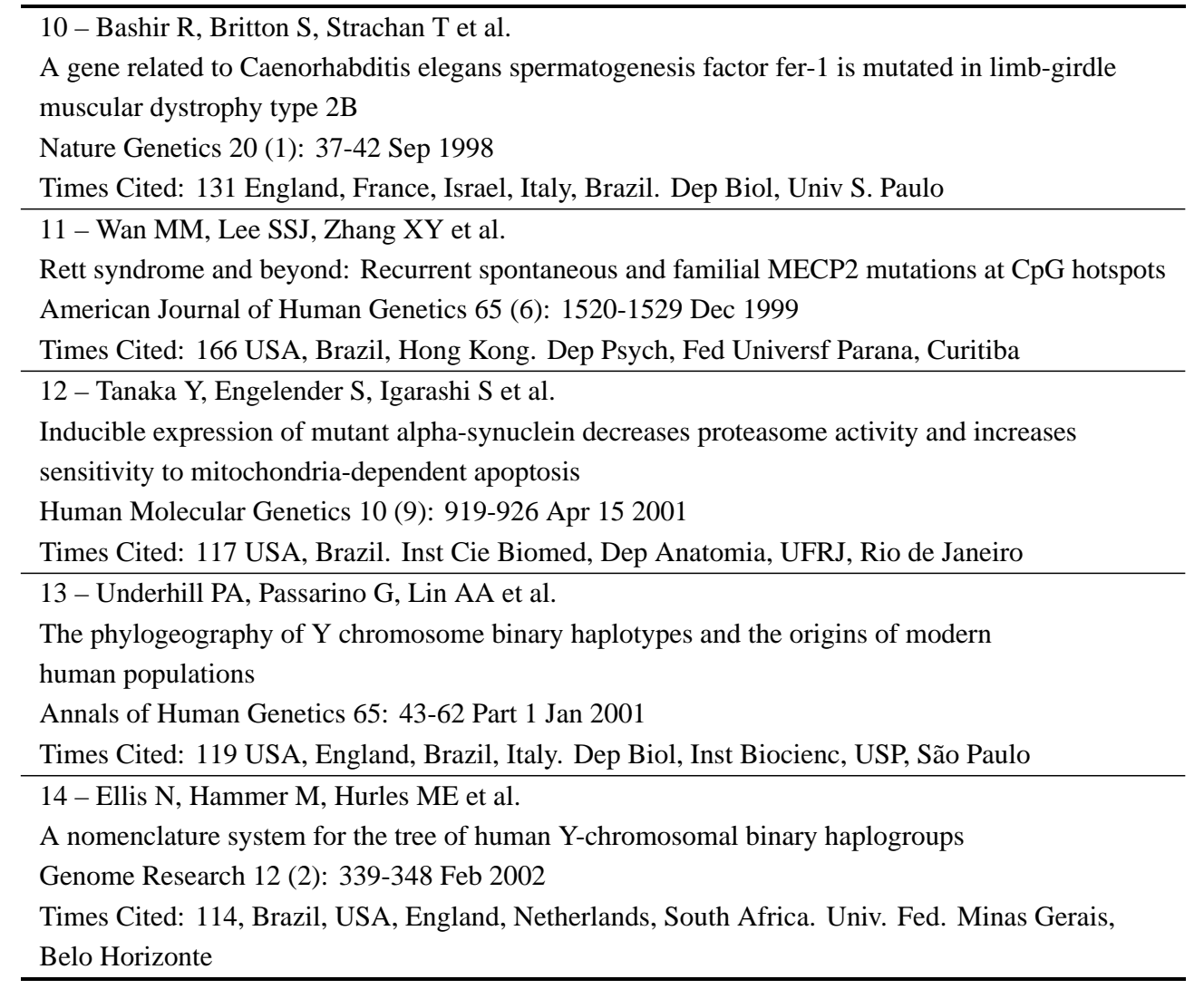

The countries mentioned in the affiliation of the articles and the Brazilian institutions to which the national authors are affiliated are indicated.

cells of the immune system) in resistance to acute infection of Toxoplasma in mice, achieved over 200 citations.

\section{EFFECTS OF CONTRACEPTIVES}

Multicenter case-control studies comprise a medical field that requires professional competence of the participants, capacity to manage the network and proficiency in statistical analysis. Several studies of this nature were detected in this survey; the discussion in Packer and Meneghini 2006 already mentioned these works. Table XII is another example of multinational networks - in this case, one group of the Escola Paulista de Medicina took part and the studies gathered approximately 40 researchers from 20 countries. All articles were published in the renowned journal The Lancet, since the effects of oral contraceptives in vascular diseases are still an issue of concern and it is important to be investigated in studies that are carefully planned and competently conducted. Nevertheless, one cannot deny that the real participation of each author in these investigations is diluted and not very perceptible.

\section{FINAL CONSIDERATIONS}

The survey of the most-cited articles has enabled a more focused evaluation of fields and competence groups regarding the number of publications or citations of individual researchers. It is sure that other ingredients beside the content of articles may contribute to that (Van der Vorst 2004). Not considering anecdotic aspects, there is a consensus that the 
TABLE XI

Most-cited articles on microbial infectious diseases.

1 - Biron CA, Gazzinelli RT

Effects of IL-12 on immune-responses to microbial infections - a key mediator in regulating disease outcome

Current Opinion in Immunology 7 (4): 485-496 Aug 1995

Times Cited: 164 USA, Brazil. Univ Fed Minas Gerais, Dept Bioq \& Imunol

2 - Gazzinelli RT, Wysocka M, Hieny S et al.

In the absence of endogenous IL-1O, mice acutely infected with Toxoplasma gondii succumb to a lethal immune response dependent on CD4(+) T cells and accompanied by overproduction of

IL-12, IFN-gamma, and TNF-alpha

Journal of Immunology 157 (2): 798-805 Jul 151996

Times Cited: 253, Brazil, USA. Germany Univ Fed Minas Gerais, Dept Bioq \& Imunol

3 - Denkers EY, Gazzinelli RT

Regulation and function of T-cell-mediated immunity during Toxoplasma gondii infection

Clinical Microbiology Reviews 11 (4): 569+ Oct 1998

Times Cited: 115 USA, Brazil. Dep Bioq \& Imunol, Univ Fed Minas Gerais

4 - Campos MA, Almeida IC, Takeuchi O et al.

Activation of toll-like receptor-2 by glycosylphosphatidylinositol anchors from a protozoan parasite

Journal of Immunology 167 (1): 416-423 Jul 12001

Times Cited: 114 Brazil, Japan, USA. Dep Bioq Imunol, Univ Fed Minas Gerais;

Ctro Pesq Rene Rachou, Fund Oswaldo Cruz Belo Horizonte; Dep Parasit, Un São Paulo;

Unidade Oncologia Exp, UNIFESP, São Paulo

5 - Cardillo F, Voltarelli JC, Reed SG et al.

Regulation of Trypanosoma cruzi infection in mice by gamma interferon and interleukin 10:

Role of NK cells

Infection and Immunity 64 (1): 128-134 Jan 1996

Times Cited: 100, Brazil, USA

Univ São Paulo, Fac Med Ribeirão Preto, Dept Imunol \& Clin Med

6 - Dewolf F, Hogervorst E, Goudsmit J et al.

Syncytium-inducing and non-syncytium-inducing capacity of human-immunodeficiency-virus

type-1 subtypes other than B - phenotypic and genotypic characteristics

AIDS Research and Human Retroviruses 10 (11): 1387-1400 Nov 1994

Times Cited: 111 Netherlands, Germany, England, Brazil, Thailand, Uganda, Switzerland, USA,

Spain, France, Sweden. Reference Lab, Salvador, BA, Brazil

7 - Vespa GNR, Cunha FQ, Silva JS

Nitric-oxide is involved in control of Trypanosoma cruzi-induced parasitemia and directly kills the parasite in-vitro

Infection and Immunity 62 (11): 5177-5182 Nov 1994

Times Cited: 129, Brazil. Univ São Paulo, Fac Med Ribeirão Preto, Dept Immunol, Dept Farmacol 
TABLE XI (continuation)

8 - Schenkman S, Eichinger D, Pereira MEA et al.

Structural and functional-properties of trypanosoma trans-sialidase

Annual Review of Microbiology 48: 499-523 1994

Times Cited: 138 Brazil, USA. Esc Paul Med, Dept Microbiol Imunol \& Parasitol, São Paulo

9 - Savino W, Dardenne M

Immune-neuroendocrine interactions

Immunology Today 16 (7): 318-322 Jul 1995

Times Cited: 108 Brazil, France. Inst Oswaldo Cruz, Dept Imunol, Rio de Janeiro

10 - Lopes MF, DaVeiga VF, Santos AR et al.

Activation-induced CD4(+) t-cell death by apoptosis in experimental Chagas-disease

Journal of Immunology 154 (2): 744-752 Jan 151995

Times Cited: 107, Brazil. Univ Fed Rio de Janeiro, Inst Microbiol, Dept Imunol; Electron

Microscopy Sect; Inst Oswaldo Cruz, Rio de Janeiro

11 - Nicholson S, BoneciniAlmeida MDG, Silva JRLE et al.

Inducible nitric oxide synthase in pulmonary alveolar macrophages from patients with tuberculosis

Journal of Experimental Medicine 183 (5): 2293-2302 May 11996

Times Cited: 196, Brazil, USA. Inst Oswaldo Cruz, Dept Imunol, Rio de Janeiro,

Univ Fed Rio de Janeiro, Hosp Univ

12 - Gao F, Morrison SG, Robertson DL et al.

Molecular cloning and analysis of functional envelope genes from human immunodeficiency

virus type 1 sequence subtypes A through $\mathrm{G}$

Journal of Virology 70 (3): 1651-1667 Mar 1996

Times Cited: 141, Brazil, USA, England, Germany, Switzerland, Rwanda, Belgium, Uganda,

Hailand, Malawi, Haiti. Dep Imunol, Instituto Oswaldo Cruz, Rio de Janeiro, Ctro Pesq Goncalo

Moniz, Fiocruz, Salvador

13 - Lowrie DB, Tascon RE, Bonato VLD et al.

Therapy of tuberculosis in mice by DNA vaccination

Nature 400 (6741): 269-271 Jul 151999

Times Cited: 156 Brazil, England, Switzerland. Dep Parasit, Microbiol Imunol, Fac Med;

Dep Anal Clin, Fac Cienc Farmac Ribeirão Preto, USP Ribeirão Preto

14 - Dewolf F, Hogervorst E, Goudsmit J et al.

Syncytium-inducing and non-syncytium-inducing capacity of human-immunodeficiency-virus

type-1 subtypes other than B - phenotypic and genotypic characteristics

AIDS Research and Human Retroviruses 10 (11): 1387-1400 Nov 1994

Times Cited: 111 Netherlands, Germany, England, Brazil, Thailand, Uganda, Switzerland, USA,

Spain, France, Sweden. Reference Lab, Salvador, BA Brazil

The countries mentioned in the affiliation of the articles and the Brazilian institutions to which the national authors are affiliated are indicated. 


\section{TABLE XII}

Most-cited articles in case studies on the use of oral contraceptives and their effects in vascular diseases.

1 - Poulter NR, Chang CL, Farley TMM et al.

Venous thromboembolic disease and combined oral-contraceptives - results of international multicenter case-control study

Lancet 346 (8990): 1575-1582 Dec 161995

Times Cited: 264 Brazil, Chile, Peoples R China, Colombia, England, Germany, Hong Kong, Hungary, Indonesia, Jamaica, Kenya, Mexico, Slovenia, Thailand, Yugoslavia, Zambia, Zimbabwe.

Esc Paulista Med, São Paulo

2 - Poulter NR, Chang CL, Farley TMM et al.

Ischaemic stroke and combined oral contraceptives: Results of an international, multicentre, case-control study

Lancet 348 (9026): 498-505 Aug 241996

Times Cited: 162, Brazil, England, Switzerland, Chile, China, Colombia, Germany, Hong Kong, Hungary, Indonesia, Jamaica, Kenya, Mexico, Slovenia, Thailand, Yugoslavia, Zambia,

Zimbabwe, USA, Denmark. Esc Paulista Med, São Paulo

3 - Poulter NR, Chang CL, Farley TMM et al.

Acute myocardial infarction and combined oral contraceptives: Results of an international multicentre case-control study

Lancet 349 (9060): 1202-1209 Apr 261997

Times Cited: 163 England, Brazil, Chile, China, Colombia, Germany, Hong Kong, Hungary, Indonesia, Kenya, Mexico, Jamaica, Slovenia, Thailand, Yugoslavia, Zambia, Zimbabwe, USA, Denmark. Esc Paulista Med, São Paulo

The countries mentioned in the affiliation of the articles and the Brazilian institutions to which the national authors are affiliated are indicated. The references are reproduced from the Webofsience - Thomson ISI tabulation.

impact of an article, measured by the number of citations, indicates one of the following possibilities: (i) seminal contributions; (ii) relevant original investigations; (iii) reviews prepared by distinguished authors showing mastery, clarity and putting forward significant new perceptions to other authors of the field. To draw attention only to total number of citations of one researcher could be useful in many contexts, but it is ideal to detect contributions that are worth mentioning. Furthermore, total citation assessment may be biased when applied to one author, such as production of many articles but none with a significant number of citations (nothing against those who are very productive, since this could deserve merit) and mastering knowledge or expensive breakthrough techniques that result in a great demand for collaborations, which is another issue that deserves merit but does not provide to such author a major intellectual contribution in the categories mentioned above (Hirsch 2005).

Recent works investigating the fields of impact on science and technology have used a methodology to search most-cited articles. Recently, King (King 2004) used this approach to assess to what extent the different countries achieved a scientific output, in terms of science and technology expenses. To this end, normalization was made for citations in distinct disciplines, as well as for year of publication of the articles. This normalization is explained because the author intended to compare different countries during two periods. In the present study, such normalization was not complied with, and the 
citation parameters were based on the ISI-Thomson database, including articles with Brazilian affiliation during a ten-year period (1994-2003). Therefore, articles with 100 or more citations were listed. The intention was not to carry out a study on temporal transitions, but to take a picture of a recent period that cannot be a snapshot, considering that to understand its purpose, a longer period (10 years) was necessary. On the other hand, it was impossible to not establish a timeframe, and by doing so, some authors were not included, although, in previous periods, they had an impact equal to or greater than that of those herein detected. These cases could be quantified by means of other methodological approaches regarding citations. It could not be denied that the 10 -year period was arbitrary. However, this decimal numeric bias is generally acceptable and protects the authors of this article against any accusation of favoritism.

In this timeframe, our primary objectives were to diagnose the fields that have major Brazilian scientific contributions at international level, to understand their genesis and consequences. We could wonder why other fields that are considered a priority in contemporary sciences and technology were not represented (information technology, nanotechnology, biosphere, materials, structure of biological and inorganic macromolecules, geological prospection). Nevertheless, it is important to mention that, to initiate this discussion, normalization by trends of citations in diverse disciplines would be needed. Thus, some fields such as Mathematics and Engineering have not been considered, as already mentioned. This normalization requires updated information from the ISI-Thomson database, which is commercially available.

A spin-off of this survey was to check the importance of multinational collaborations in works conducted or not in networks. (Aksnes and Sivertsen 2004, Meneghini 1996, Leta and Chaimovich 2002, Harvey and McMeekin 2005) In both cases, the participation of authors with foreign affiliation in ISI journals was much greater than the total number of articles with Brazilian affiliation. Further- more, these collaborations were primarily with authors from developed countries. Hence, an important issue concerning scientometrics and bibliometrics arise: to what extent does this fact results from collaborations with scientifically strong groups from these countries or from an impact favored by greater influence of these international authors in the scientific community? There is no single answer and it definitely demands data that are not currently available.

Another scientometric issue resulting from this survey refers to the credit of citations of authors who belong to networks with several researchers as opposed to those operating more traditionally, that is, with a limited number of authors. Certainly, this is a concern of those studying information science who do not find support in more consensual rules. A recent work has advanced possibilities to deal with such situations (Hirsch 2005).

The limited set of articles and of groups in charge of authorship in the present study shows that a few can make a huge difference in an institutional or regional context. Taking into account the dual function of citations as a means of recognition by the peers and of symbols established for specific scientific achievements (Small 2004), one group of excellence detected by this approach have outstanding visibility, so that if moving from one institution to another, they bring their prestige to the new place of work. This migration is not frequent in Brazil, but it occurs quite often abroad, mainly in the United States and, to a certain extent, it is similar to transfer of famous soccer players between teams. The likelihood of few investigators unbalancing a collectivity may be observed in Figures 1 and 2 (Packer and Meneghini 2006), both at institutional and regional levels. The lines connecting the most-cited articles to the number of ISI publications are not parallel and divert upwards or downwards.

The inclusion of some groups or fields of research detected in this study is not surprising for those who closely follow up the development of Brazilian sciences. The scientific media has progressed much in the past ten years, and particularly 
the major national newspapers now dedicated more space to sciences. It means that the lay readers can have access to and get interested in scientific matters. We did not conduct an extensive survey of the achievements herein mentioned that resulted in reports in recent newspapers, but can state that at least $55 \%$ of them became news, which is a reasonable percentage considering what the scientific journalism values and the scientific community detects. The remaining $45 \%$ are more related to a limited sphere of scientists. These comparisons also deserve a more elaborated study, since scientometrics is interested in gathering impact detection tools not only in academic settings and in ISI database, but also in the general public. Above all, these individuals contribute most to conduction of scientific investigations and are very much interested in their results.

\section{ACKNOWLEDGMENTS}

The authors thank Maria Regina Rangel Braga and Rosely Fátima Pellizzon and their team for assisting in the searches on ISI database.

\section{RESUMO}

Foram identificados os artigos com um mínimo de 100 citações na literatura científica e com ao menos uma filiação brasileira, segundo Thomson-ISI (Institute for Scientific Information) Web of Science bibliometric database, no período de 10 anos entre 1994 e 2003 (veja Packer and Meneghini 2006). Este levantamento foi feito primordialmente para identificar núcleos temáticos de excelência em pesquisa que tiveram maior impacto na literatura internacional. Doze núcleos, nas áreas biomédica, médica, biológica, física, química e astronomia foram considerados proeminentes e suas gêneses e desenvolvimento foram descritos. Os pesos de fatores como colaboração internacional e organização de trabalho em rede são distintos em cada uma dessas áreas. São discutidas as razões para isso.

Palavras-chave: bibliometria, serviços de informação, armazenamento e recuperação da informação, ciência, cienciometria, fator de impacto, política científica, instituições científicas, Brasil.

\section{REFERENCES}

Aksnes DW And Sivertsen G. 2004. The effect of highly cited papers on national citation indicators. Scientometrics 59: 213-224.

http://www.springerlink.com/media/ 92xd8tgb7m7jyv4d5v56/contributions/n/1/6/7/ n167344122728752.pdf

Garfield EM And Small H. 1978. Citation Data as science indicators. In: ELKANA Y, LEDERBER J, MERTon RK, THACKRAY A AND ZUCKERMAN $\mathrm{H}$ (Eds), Toward a metric of science: the advent of science indicators. New York: J Wiley \& Sons, p. 179-207.

HARVEY M AND MCMeEKIN A. 2005. Brazilian genomics and bioinformatics: instituting new innovation pathways in a global context. Economy and Society 34: 634-658.

http://les.man.ac.uk/cric/workshops/frontiers/ papers/harvey.pdf

HIRSCH JE. 2005. An index to quantify an individual's scientific research output. Proc Natl Acad Sci USA 46: 16569-16572. http://polymer.bu.edu/hes/articles/rp-hirsch05.pdf

KING DA. 2004. The scientific impact of nations. Nature 430: 311-316.

http://www.nature.com/nature/journal/v430/ n6997/full/430311a.html

LeE KP, Schotland M, Bacchetti P AND Bero LA. 2002. Association of journal quality indicators with methodological quality of clinical research articles. JAMA 287: 2805-2808.

http://jama.ama-assn.org/cgi/content/abstract/ 287/21/2805

Leta J And Chaimovich H. 2002. Recognition and international collaboration: the Brazilian case. Scientometrics 53: 325-335.

http://www.springerlink.com.w10080.dotlib.com.br /media/d86tgdpwwn5yqvb7tpq0/contributions/ 5/h/4/b/5h4blf60q82kj83v.pdf

Meneghini R. 1996. The key role of collaborative work in the growth of the Brazilian science in the last ten years. Scientometrics 35: 367-373. http://www.springerlink.com.w10080.dotlib.com.br /(ncg1sly0gghdhd552xh45bva)/app/home/ contribution.asp?referrer=parent\&backto= searcharticlesresults,2,2 
MoEd HF. 2005. Citation analysis in research evaluation. Netherlands, Springer.

OPPENHEIM C. 1997. The correlation between citation counts and the 1992 research assessment exercise ratings for British research in genetics, anatomy and archaelogy. J Doc 53: 477-487.

http://www.emeraldinsight.com/Insight/ ViewContentServlet?Filename=Published/ EmeraldAbstractOnlyArticle/Pdf/2780530502.pdf

Packer AL And Meneghini R. 2006. Articles with authors affiliated to Brazilian institutions published from 1994 to 2003 with 100 or more citations: I The weight of international collaboration and the role of the networks. An Acad Cienc 78: 841-853.
SAHA S, SAINT S AND Christakis DA. 2003. Impact factor: a valid measure of journal quality? J MedLibr Assoc 91: 42-46. http://www.pubmedcentral.nih.gov/ articlerender.fcgi? artid=141186

SMALL H. 2004. On the shoulders of Robert Merton: Towards a normative theory of citation. Scientometrics 60: 71-79.

http://www.springerlink.com/media/ e05d2179qkdqwvcarecn/contributions/x/6/v/t/ x6vtvm1209131570.pdf

VAN DER VORST. 2004. How to write a frequently cited article. http://www.austms.org.au/Gazette/2004/ May04/vorst.pdf 